\title{
Research and Patent of Phytotherapeutic and Phytocosmetic Products in the Brazilian Amazon
}

\author{
Fabiana dos Santos e Souza Frickmann',Alexandre Guimarães Vasconcellos ${ }^{2}$
}

\begin{abstract}
The aim of this study is to analyze the research and the patent of phytotherapeutic and phytocosmetic products in the Brazilian Amazonia, in order to identify the current landscape of these markets and propose actions to leverage the development of these industrial sectors. The data analyzed proceed from research groups of the National Council of Scientific and Technological Development (CNPq) and patents applications from the National Institute of Industrial Property (INPI). Our results showed the existence of 86 regional research groups and 35 patent applications and none can be related to Amazonian companies. Legal impediments of the Provisional Measure 2.186-16/200I, in relation to applications for inventions by individuals, may result in refusal of the patent, representing a significant loss of Amazon innovative effort and reduction in the development of these sectors in the Brazilian Amazonia.
\end{abstract}

Keywords: Brazil; amazon; biodiversity; biotechnology; herbal medicine; phytocosmetic; phytotherapeutic; research groups; patents; public policy.

\footnotetext{
' Doctor's degree student of the Plant Biotechnology Program at Federal University of Rio de Janeiro (UFRJ), Health Science Center (CCS). Phone number: +55 (2I) 2562-6676. FAPEAM fellowship holder. Address: BI. K/ S. K2-032, Cidade Universitária, Zip Code: 2194I-590. City: Rio de Janeiro/RJ. Country: Brazil. Email: fasect@yahoo.com.br.

${ }^{2}$ Researcher and Permanent Profesor. National Institute of Industrial Property (INPI).Address: Praça Mauá 7, sala 709, Centro. City: Rio de Janeiro/RJ. Country: Brazil.Zip Code: 2008I-240. Phone number: +55 (2I) 3037-3543. Postdoctoral researcher at CDTS/FIOCRUZ, INCTNeglected Diseases, Supported by FAPERJ. Email: alexguim@inpi.gov.br.
} 


\section{Introduction}

Brazil possesses strategic conditions to generate innovations and obtain a worldwide prominent position in the exploitation of knowledge associated to biodiversity (Vasconcellos and Rodrigues, 2008). The Brazilian Amazonia is a single natural asset that could offers to Brazil competitive advantages in the global biotechnology industry. The Tropical Rain Forest presents high diversity of organisms and, mainly, microorganisms, which are insufficiently inventoried yet (Miguel, 2007). The scientific benefits from a better understanding about the Amazonian biologic diversity are extensive, due to economic importance to these organisms for the production of new antibiotics, therapeutic agents, probiotic agents, chemical products, enzymes, polymers, pollutants bioremediator agents, biolixiviation agents, etc (Fonseca, Poz and Silveira, 2004).

Currently, the Amazonian Region presents important scientific institutions installed over there, such as Brazilian Company of Agricultural and Cattle Breeding Research (Embrapa) Western Amazonia and Eastern Amazonia, National Institute of Amazonian Research (INPA), Emílio Goeldi Paraense Museum (MPEG), Institute of Researches in Tropical Pathologies (IPEPATRO), Foundation of Tropical Medicine of Amazonas (FMT/AM), Oswaldo Cruz Foundation (FIOCRUZ), among others. The conversion of scientific research about Amazon biodiversity into commercial products is a national challenge, as new scientific discoveries about Amazon biodiversity will enable the development of innovations in the biotechnology sector, which will be potentially applicable to different fields, such as pharmaceutics, cosmetics, and nutrition. However there is a lack of large companies installed in the Brazilian Amazon, which could offer the technological development of regional products based on biodiversity (Frickmann and Vasconcellos, 2010) to global markets.

Authors such as Becker (2009) and Arruda (2008) list the segments productive strategy for the generation of Amazon technological innovations. Two of this segments are phytotherapeutic and phytocosmetic agents, which are inserted in the new paradigm of social and economic development based on renewable resources and are also currently in expansion (Hasenclever et. al., 2009).

The international market of therapeutic agents based on plants moved in 2000, in the USA and Europe, about US\$6.3 and US\$8.5 billion, respectively (Simões and
Schenckel, 2002). In Brazil, Freitas (2007) has calculated that the Brazilian phytotherapeutic agents segment has invoiced, in the period of 2003 November to 2006 October, the amount of US\$1.086 billions with the sale of 122.3 millions pharmaceutical units, or medication packages. According to Hasenclever et. al. (2009), the segment of phytotherapeutic agents had an accelerated increase of invoicing, which was of $10 \%$ in the year of 2005 , and higher than $18 \%$ in the year of 2006.

According to Arruda (2009) based on the data from the Brazilian Association of Personal Hygiene, Perfumery, and Cosmetics Industry (ABIHPEC), the Brazilian market of cosmetic agents closed the year of 2005 with a liquid invoicing of US\$8.7 billion, and a sales increase of $15.8 \%$ over the previous year.

In the $X X I$ century, the Brazilian Amazonian looks to congregate brand new factors for the configuration of a scenery promising for the development of innovations in strategic Brazilian sectors, such as phytotherapic and phytocosmetic ones. Therefore, this study analyzed the management of scientific knowledge about Brazilian Amazonia biodiversity, from the point of view of its diffusion and application in the generation of Technological Product \& Process (TPP) inventions of phytotheraputical and phytocosmetic sectors.

In line with the Oslo Manual (OECD, 2005) there are two basic families of scientific and technological (S\&T) indicators which are directly relevant to the measurement of TPP innovation: resources devoted to research and development (R\&D) and patent statistics. In this way the present research has verified the amount of scientific production in the Brazilian Amazonian institutions that is, effectively, being converted into technological development for the phytotherapics and phytocosmetics sectors. 


\section{Objective}

To investigate the existing research groups in the Brazilian Amazonia studying medicinal plants, and the phytotherapical and phytocosmetic sectors verifying also the occurrence of Brazilian patent applications in these sectors, which originated from Amazonian States; all of this in order to identify the current main challenges for the development of innovations in these sectors, in that region.

\section{Materials \& Methods}

In accordance with to geopolitical classification of 1966, the territory of Legal Amazonia includes nine States: Acre (AC), Amapá (AP), Amazonas (AM), Mato Grosso (MT), Pará (PA), Rondônia (RO), Roraima (RR), Tocantins (TO) and also, but only partially, the State of Maranhão (only the State part western to $44^{\circ}$ West Greenwich meridian), totalizing a surface of approximately 5,217,423 km² (Brasil, 2010a).

The research about scientific knowledge of medicinal plants, and the Brazilian Amazonia phytotherapeutical and phytocosmetic sectors has been developed through a survey of existing research groups, and records about research groups in the CNPq website (http://dgp.cnpq. br/buscaoperacional/). The CNPq is an agency of the Ministry of Science, Technology and Innovation (MCTI) of Brazil, whose purpose is to work for the promotion of scientific and technological research and training of human resources for research in Brazil. The Brazilian researchers need to participate in research groups and to carry out these groups registration in the Directory of Research Groups from the CNPq, in order to obtain public funding from this council.

Thus, this study considers the main Brazilian research groups; those who get public funding and figure between the Brazilian public research institutions that are registered in the CNPq Directory of Research Groups. The research for identification of the CNPq Research Groups working with medicinal plants, phytotherapeutic and phytocosmetic agents present in the Brazilian Amazonia, was developed using the following three (03) keywords: plantas medicinais (medicinal plants, as exact phrase), fitocosméticos (phytocosmetic) and fitoterápicos (phytotherapeutical). In the searching filters section, research group $\mathrm{UF}^{3}$ item, the respective abbreviation of the nine states composing the Legal Amazonia was selected: AC, AP, AM, MA, MT, PA, RO, RR, TO.

The search about patents applications was performed in the National Institute of Industrial Property (INPI) database, done within the A6IK class of the International Patent Classification (IPC), which is referred to preparations for medical, odontological, or personal hygiene use. The time interval was the period from 1982 to 2009 , and the geographic area was the Legal Amazonia States. The study involved Invention Patents, Utility Models and Invention Addition Certificates originated from Brazilian Amazonia States. Such data were registered and, using the Microsoft Office Excel 2007 software, inserted into tables containing information about: the inventors, the applicants, the patent titles, and the year of application. After that, the applications related to phytotherapeutic and phytocosmetic products were selected by abstract reading and further analyzed.

\section{Results}

Respecting to research groups in the fields of medicinal plants (Mp), phytotherapeutic (Pt) and phytocosmetic products $(\mathrm{Pc})$ existing in the Brazilian Amazonia, the State of Amazonas was the one presenting the largest number of research groups, when summed the three categories without the inclusion of research groups repeated in the different categories $(M p=13 ; P t=6 ; P c=0$; Sum without repetition $=16)$. The repetitions occurred, because some research groups have utilized both, the keyword phytotherapeutic and the keyword phytocosmetic, in their own description.

The State of Pará was the most diversified $(\mathrm{Mp}=\mathrm{II} ; \mathrm{Pt}$ = 8; $\mathrm{Pc}=1$; Sum without repetition $=14$ ) and abundant respecting to other States possessing research groups in the three analyzed categories, such as, for instance, the Amapá (Mp = 3; $\mathrm{Pt}=1 ; \mathrm{Pc}=1$; Sum without repetition =4). The Maranhão State does not possess any research group in phytocosmetic agents $(\mathrm{Mp}=10 ; \mathrm{Pt}=4 ; \mathrm{Pc}=$ 0 ; Sum without repetition $=12$ ), as well as the States of Mato Grosso $(\mathrm{Mp}=10 ; \mathrm{Pt}=\mathrm{I} ; \mathrm{Pc}=0$; Sum without

${ }^{3}$ Federation Unit 
repetition $=1 \mathrm{I})$, Tocantins $(\mathrm{Mp}=5 ; \mathrm{Pt}=5 ; \mathrm{Pc}=0$; Sum without repetition $=10)$, Acre $(M p=3 ; P t=1 ; P c=0$; Sum without repetition $=3)$, and Roraima $(M p=1 ; P t$ $=$ I; $P_{c}=0$; Sum without repetition $=2$ ). The State of Rondônia has presented only one research group using the keyword 'medicinal plants' (Figure I).

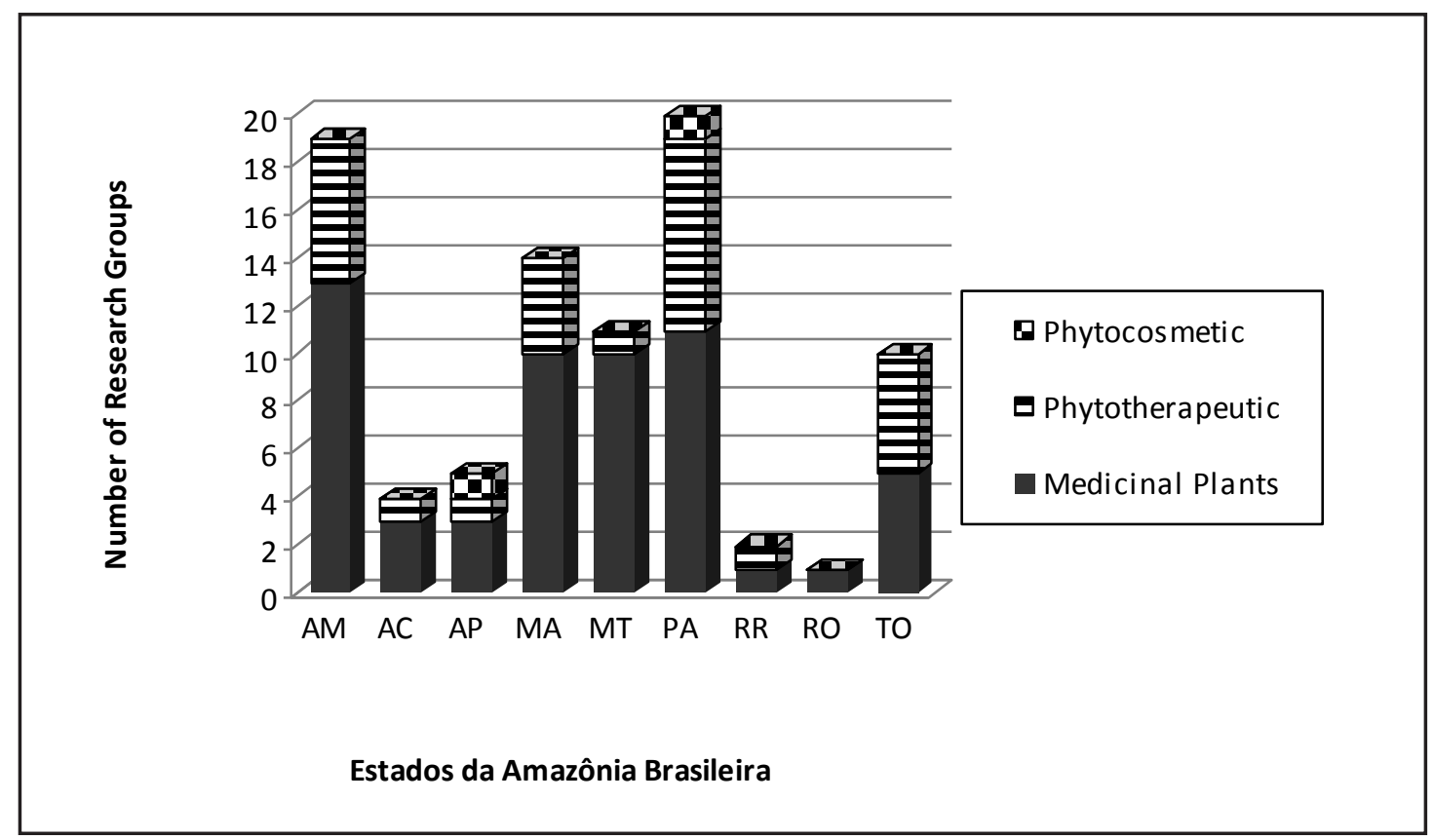

Figure I: Distribution of the amount of CNPq research groups, per Brazilian Amazonia State in 2010.

Only two research groups of Brazilian Amazonia have utilized the keywords 'phytocosmetic'. These research groups were the following ones: 'Development and Innovation of Pharmaceutical and/or Cosmetic Products' of the Federal University of Pará (UFPA) formed in 2009, which develops investigation in a cooperative system with the Federal University of Pernambuco (UFPE) and the Federal University of São Paulo (UNIFESP) to obtain and characterizestandardized plantextracts for pharmaceutical and cosmetic use; and the research group of the State of Amapá, which is named 'Technological Development' of the Institute of Scientific and Technological Researches of the State of Amapá (IEPA).

Comparing the research groups found at Brazilian Amazonia to research groups found all over the Brazilian territory and utilizing the same keywords, the Amazon research efforts represent the following fractions: (I)
II.9\% of all Brazilian groups investigating medicinal plants [Number of Amazon (NA) = 57; Number of Brazilian (NB) = 479]; (2) $14.5 \%$ of all groups investigating phytotherapeutic agents $(\mathrm{NA}=27 ; \mathrm{NB}=186)$, and (3) $40 \%$ of all groups investigating phytocosmetic agents (NA $=2 ; \mathrm{NB}=5$ ) of the total Brazilian research groups.

There is eighty six (86) research groups involved with medicinal plants, phytotherapic and phytocosmetic research in Science and Technology Institutions (STI) of Brazilian Amazonia, registered in the Carlos Chagas Platform of CNPq. The types of Science and Technology Institutes (STI) types of Brazilian Amazonia, effectively presenting research groups registered in the Carlos Chagas Platform of CNPq are: universities (78\%), research institutes (14\%), museums (2\%), foundations (1\%), and companies (5\%), as observed at figure 2 . 


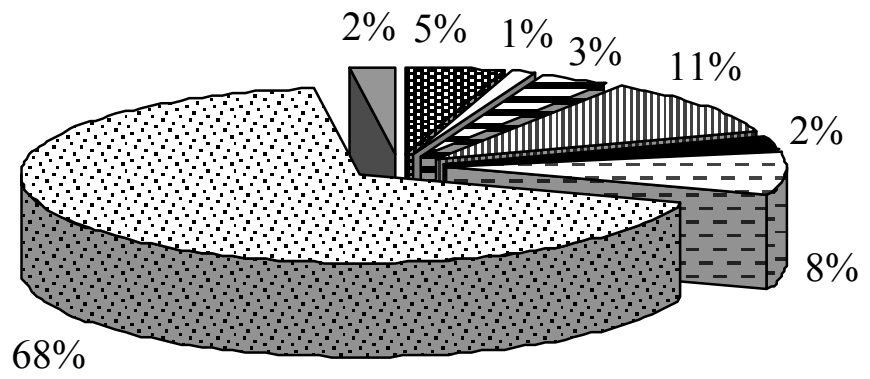

\begin{tabular}{|l}
\hline 㽗 Companies \\
$\square$ Foundations \\
$日$ State Institutes \\
m Federal Institutes \\
$\square$ Museums \\
$\square$ State Universities \\
$\square$ Federal Universities \\
$\square$ Private Universities
\end{tabular}

Figure 2: Distribution of research groups involved with medicinal plants, phytotherapic and phytocosmetic by Brazilian Amazonia, per category of STI, in 2010.

Sixteen universities were found, out of which ten (I0) are federal, three (03) are state, and two (2) are private universities. Such universities are distributed among all Amazon States. The Federal Universities are: Federal University of Acre (UFAC), Federal University of Amazonas (UFAM), Federal University of Maranhão (UFMA), Federal University of Mato Grosso (UFMT), Federal University of Pará (UFPA), Federal Rural University of Amazonia (UFRA), Federal University of Roraima (UFRR), Federal University of Tocantins (UFT), Federal University of Amapá (UNIFAP), Federal University of Rondônia (UNIR). The State Universities are: State University of the State of Amazonas (UEA), State University of Maranhão (UEMA), University of the State of Pará (UEPA) and University of the State of Mato Grosso (UNEMAT). The Private Universities investigating phytotherapeutic and phytocosmetic agents at Amazonia are the Uninilton Lins (Nilton Lins University Center) and Ulbra (Lutheran University of Brazil).
The STI found were: INPA (National Institute of Amazonian Research), IFAM (Federal Institute of Amazonas), IFMA (Federal Institute of Maranhão), and IEPA (Institute of Scientific and Technological Researches of the State of Amapá). It was found also a Museum, the MPEG (Paraense Emílio Goeldi Museum), a Foundation, the FMT (Tropical Medicine Foundation of Amazonas) and a Company, the EMBRAPA (Brazilian Agricultural Research Corporation). Altogether $23 \mathrm{STI}$ were found, $91.3 \%$ of them are institutions developing research about medicinal plants, $65.2 \%$ develop research about herbal medicines and $8.75 \%$ conduct research about phytocosmetic agents. The distribution of research groups investigating the fields of phytotherapeutic agents, phytocosmetic agents, and medicinal plants of these institutions can be visualized at figure 3 . 


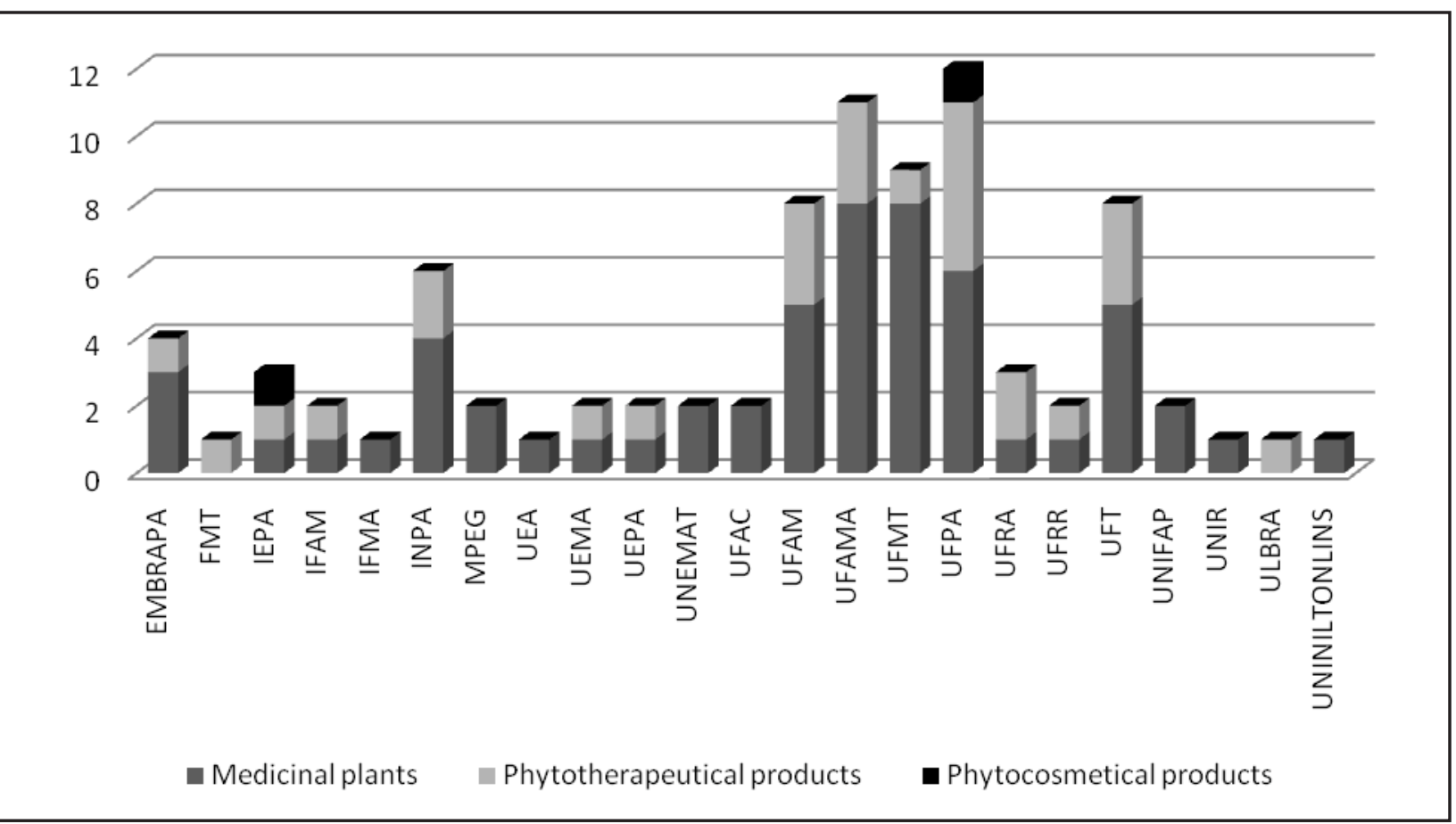

Figure 3: Distribution of research groups investigating phytotherapeutic agents, and phytocosmetic agents, and medicinal plants, per Amazonian institution until 2010.

Respecting to intellectual protection strategies employed for the Amazon bioproducts of personal hygiene and health sectors, inserted in the Class A6IK of IPC (International Patent Classification) by Amazonian institutions, 35 patent applications were found. These deposits are referred to processes for obtainment of plant extracts, formulations, odontological compositions with plant resources, manufacture methods of gels based on Amazonian plants, formulation of toilet soaps and shampoos, solutions with antibacterial activity, active substances, phytotherapeutic agents for the treatment of diseases such as hemorrhoids, AIDS, diabetes, cancer, and asthma; rejuvenators, cosmetic composition, chemical composition, medications and even herbicides, including also products involving mystical elements, such as, for instance, a patent application titled "Água Milagrosa" (Miraculous Water).

The patent applications analysis has indicated that $56 \%$ of them presented, in the product description, the utilization of plant resources such as, andiroba (Carapa guianensis Aublet, botanic family Meliaceae), copaiba (Copaifera multijuga Hayane, botanic family Leguminosae), murumuru (Astrocaryum murumuru Mart, botanic family Arecaceae), chapeu-de-couro [Echinodorus macrophyllus (Kunth) Micheli, botanic family Alismataceae], catinga de mulata (Tanacetum vulgare L., botanic family Compositae), limão tanjalo (Citrus nobilis Lour., botanic family Rutaceae), Vernonia sp., Açacur (Hura crepitans L., botanic family Euphorbiaceae), Astronium urundeuva Engl., botanic family Anacardiaceae, barbatimão (Stryphnodendron adstringens (Mart.) Coville, botanic family Leguminosae), Piper aducum L. (botanic family Piperaceae) and vassourinha (Scoparia dulcis L., botanic family Plantaginaceae). Such patent applications were classified and subdivided into: $40 \%$ of phytotherapeutic agents $(\mathrm{N}=15), 17 \%$ of phytocosmetic agents $(\mathrm{N}=7)$, and $43 \%$ of other types of Class $A 6 I K$ products $(N=13)$.

The Amazon patent applications of A6IK Class of IPC represent about $0.1 \%$ of patent deposits done in Brazil within this CIP field, as 31.700 patent deposits have been found at INPI database (04/18/20II) having A6IK classification. The States of Amazonas and Mato Grosso were the Amazonian States that most deposited patent applications of phytotherapeutical agents ( $N=4$ for each). The Amazonas State, similarly to Mato Grosso State, had two $(\mathrm{N}=2)$ of its patent applications for phytotherapeutical agents filed; the remaining patent applications for phytotherapeutical agents of these states continue to follow their normal course at INPI. 
The State of Acre had the leadership in patent applications for phytocosmetic agents, with three $(\mathrm{N}=3)$ requests deposited and following the normal course at INPI, in the year of 2010. The State of Pará has thirteen $(\mathrm{N}=13)$ patent deposits in the class $A 6 I K$; but out of them, only two $(\mathrm{N}=2)$ were for phytocosmetic agent, and one $(N=I)$ for phytotherapeutic agent. Between the three $(\mathrm{N}=3)$ patent applications for "phytoproducts" of Pará, one for phytocosmetic agent was filed, the remaining are following the normal course at INPI. The State of Maranhão has developed two $(\mathrm{N}=2)$ patent applications for phytotherapeutic agent, and one $(\mathrm{N}=$ I) for phytocosmetic agent. The States of Rondônia, Tocantins, and Amapá have all requested one patent for phytotherapeutic agent ( $\mathrm{N}=\mathrm{I}$ for each). The requests of Amapá and Tocantins were filed. The State of Roraima has requested neither phytotherapeutical patents, nor phytocosmetic patents, as evidenced at figure 4 .

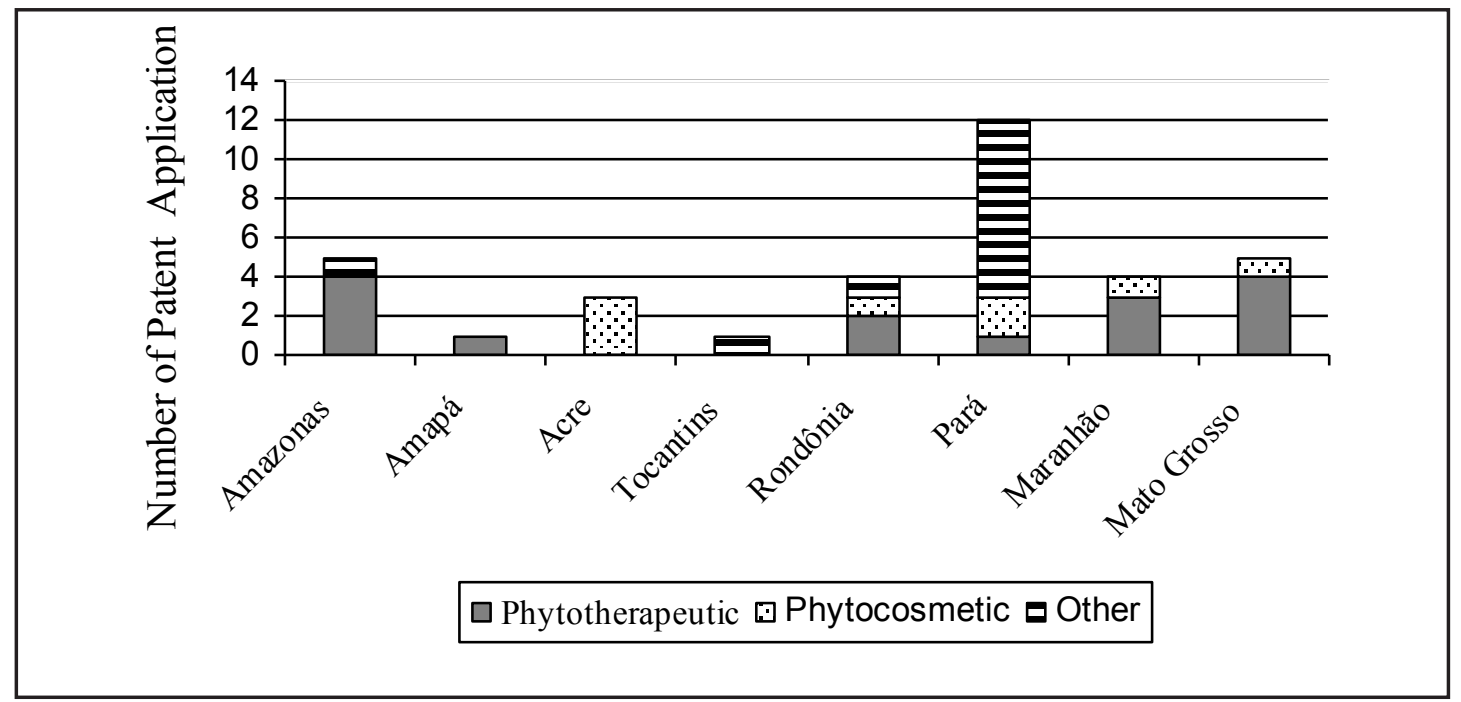

Figure 4: Patent applications in the period between 1982 and 2009, within the A6IK class of the IPC, originated from Amazon States.

The patent applications originated from Amazon States and related to phytotherapeutic and phytocosmetic sectors deposited at INPI were in their majority, that is, $91 \%$, requested by natural persons (PF); only one $(N=I)$ of the found patent deposits was done in co-titularity, being requested by a company settled in São Paulo/Brazil (Natura Cosméticos S.A), in partnership with a company in the state of Pará/Brazil (Cia. Refinadora da Amazônia). Such patent was requested in the State of Pará, in 2004, and it is titled "Cosmetic composition embracing lipidic fraction of plant origin and anti-crystallizing agent". No deposit of Invention
Patent (PI), Utility Model (MU), and Certificate of Invention Addition (C) was done by a Brazilian Amazonia company, at the National Institute of Industrial Property (INPI).

It was also found a patent application on behalf of University of Amazonas Foundation (FUA) and Teaching Association of Ribeirão Preto/SP, indicating a scientific partnership between these research institutions for the production of biotechnological inventions based on Amazonian plant resources. Figure 5 represents the percent distribution of these patents depositors.
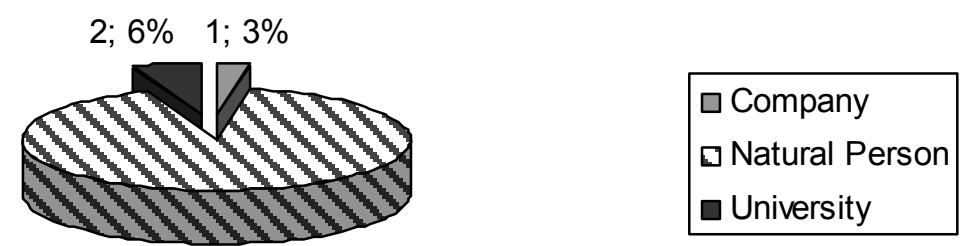

$32 ; 91 \%$

Figure 5: Percent distribution of patent applications of A6IK class of the IPC, originated from Amazon States, done in Brazil in the period between 1982 and 2009. 


\section{Discussion}

The results of this investigation reveal that the Brazilian Northern Region is starting an of arrangement process for its research groups in the area of phytotherapeutic and phytocosmetic agents, and the participation of these groups in the Brazilian scenery is relevant. This because, taking into account the total number of 87,063 individuals with doctorate level (PhD) in Brazil, in period 19962008 years (Brasil, 20l0b), only 5\% of them, working in the Amazon Region were able to produce $14.5 \%$ of Brazilian research groups investigating phytotherapeutic agents and $40 \%$ of Brazilian research groups investigating phytocosmetic agents. However, for further participation analysis of the Amazonian research groups in the Brazilian scenery, other parameters such as impact of scientific publications, should be considered and analyzed in conjunction with the data presented in this study.

The Amazonian biodiversity linked to the pioneer character of these investigations could effectively represent a promising expectation for the regional and Brazilian development, in the sector of cosmetic and dermocosmetic agents; firstly, by the elucidation of properties of these Amazonian genetic resources, and secondly, by the perspectives that this fact represents in the international scenery.

In this case, the State of Acre possesses the largest number of deposits in the phytocosmetic sector, indicating a protection expectation for inventions of this technological field and, consequently, an interest in the generation of innovations in this sector, with three $(n=$ 3) patent applications deposited, published, and in course at INPI. The State of Pará congregates both, the scientific research produced by the CNPq research group titled "Development and innovation of pharmaceutical and/ or cosmetic products", and the technological invention indicated by the patent "Cosmetic composition embracing lipidic fraction of plant origin and anti-crystallizing agent", which was requested by the Natura company S.A and Cia. Refinadora da Amazônia. Part of this scientific and technological advancement in the State of Pará could be a direct consequence of the presence of large São Paulo companies over there, such as Natura S.A. and Beraca Sabará; such installation is also important, because it results in generation of employments, taxes income, transference of technology from the country Southern Region to country Northern Region, and production of patents in the Amazonia.

In the State of Amazonas, there is the experience of the Industrial Pole of Manaus (PIM), which in 2009 has moved about US\$II.4 million in a business enterprise promoted by the Superintendence of Manaus Free Zone (SUFRAMA), being demanded on that occasion, mainly, products as handicrafts, phytotherapeutic agents, furniture, wood artifacts, regional fruits (in natura, jams, and pulps), fish, foods and beverages (candies, biscuits, and spirits), plant extracts and oils, natural colorants, medicinal and aromatic herbs. The Brazilian buyer companies came from I5 Brazilian states, and the international ones came from 13 different countries (Brasil, 2010c).

According to Arruda (2009), Amazonas is the more technoscientifically organized state for the development of dermocosmetics ${ }^{4}$, because it detains the largest scientific knowledge about the productive chains of the most utilized regional raw materials, such as andiroba, copaiba, and castanha-do-pará. Arruda (2008) points also for the important existence of the Amazon Biotechnology Center (CBA), which has as mission to promote the technological innovation of processes and products, stimulating and creating the basic conditions to support the development of industrial activities based on the sustainable exploitation of Amazonian biodiversity.

Another important differential of Amazonas is the existence of the State Law of Technological Innovation (Law \# 3.095/2006), which created the possibility of "incentives to innovations and scientific/technological research in the productive environment". The existence of Foundation for support of research in the State of Amazonas (FAPEAM) has been also fundamental for the regional development, that invested US\$98.5 million in research \& development (R\&D) in the interval between 2003 and 2008 (Amazonas, 2009) and, currently, it constitutes the main regional source of non-reimbursable public investments for R\&D in the areas that were characterized by the 2007-2010 Action Plan of MCTI, as "future holders" in the Northern Region.

\footnotetext{
${ }^{4}$ Cosmetic products containing bioactive ingredients with therapeutic properties for skin treatment.
} 
In this sense, the arrangement of Amazon R\&D system has amplified the frame of regional doctors, by means of actions like the Human Resources (HR)-Postgraduate, HR-Interiorization, HR-Inter-institutional, HR-Doctorate programs of FAPEAM, adjusting the intellectual utilization of Amazon professionals with that of the remaining areas of the Brazil. These actions are of extreme importance for the Amazon technological and scientific development, once that, according to Cruz (1999), the progress in R\&D is directly related to the presence of professionals, such as scientists and engineers developing their activities.

Other actions directly related to the development of "Phytos" sector are being implemented with the support of the Amazon Programme Support Research in Business (PAPPE) of FAPEAM Edict. It has invested US\$3.5 million in the regional Micro and Small Businesses for the development, among other products, of castanhado-brasil, phytotherapeutic and phytocosmetic agents, pulp, extracts, and concentrates of regional fruits and environmental services (Amazonas, 2007a). This action stimulates also the development of Local Productive Arrangements (APLs), according to Plans of Preliminary Development (PDP), financing the research of Amazon botanical species with some demand and associated production, in order to transform them into technological products, such as: (I) Unha de gato - Uncaria tomentosa (Willd. ex Schult.) DC. - Rubiaceae; (2) Muirapuama Ptychopetalum olacoides Benth. - Olacaceae; (3) Pedrahume-caá - Myrcia citrifolia (Aubl.) Urb. - Myrtaceae; (4) Chichuá - Maytenus guyanensis Klotzsch ex ReissekCelastraceae; (5) Mulateiro - Calycophylum spruceanum (Benth) Hook F. ex. Schum.- Rubiaceae; (6) Preciosa Aniba canellila (Kunth) Mez - Lauraceae; (7) Crajirú Fridericia chica (Bonpl.) L.G.Lohmann. - Bignoniaceae; (8) Cupuaçú - Theobroma grandiflorum (Willd. ex Spreng.) K.Schum. - Sterculiaceae; (9) Buriti - Mauritia flexuosa L.f.. - Arecaceae; (10) Patauá - Oenocarpus bataua var. bataua - Areacaceae; (II) Pau-Rosa - Aniba rosaeodora Ducke. - Lauraceae.

Other programs like PIPT ${ }^{5}$, the Science and Technology Program for the Green Amazonas and the PPOPE ${ }^{6}$ developed forest inventories and researches in conjunction with traditional populations, in the community of Silves/ AM, for the development of protocols of in vitro propagation of andiroba, building of vivariums of copaiba, preciosa, and andiroba seedlings, and supplementary issues analyzed for the improvement of local populations quality of life, such as territorial demarcation, cultural and linguistic rescue, forest resources management, etc.

In the Rural Settlement of Cristo Rei do Uatumã, research groups of institutions such as INPA and UFAM have offered management courses, and built a forest vivarium with pau-rosa, andiroba, copaiba, and amapá seedlings, besides to analyze the traditional handling techniques of the liana saracura-mirá or cerveja-de-índio (Ampelozizyphus amazonicus Ducke, botanic family Rhamnaceae) which is utilized as antimalarial; these research groups have also inventoried the region, observing the potential for nonwood exploitation (Amazonas, 2007b).

This way, the implementation of FAPs (State Foundations of Research Support) in the Brazilian Amazonia constitutes a tool to ease the lack R\&D investments in the region; and the absence of FAPs in states such as Rondônia, Roraima confines the states research nuclei in a vicious circle, where critical mass of technical-scientific competence is not built due to the lack of resources, and resources lack due to the absence of this critical mass (Jornal da Ciência, 2009).

In this work, such argument was evidenced in states lacking FAPs up to the year of 2009, where the number of research groups investigating "Phytos", and their respective patent applications, were lower; and in Roraima, where no patent application to INPI has occurred. The results of this work point also to the relevance of public research institutions, mainly the federal ones, for the development of scientific research of Amazonian phytotherapeutical and phytocosmetic agents, such as the Federal Universities. However, it is emphasized that such patent applications have very low success rate in Brazil.

\footnotetext{
${ }^{5}$ Programa Integrado de Pesquisa e Inovação Tecnológica or Integrated Program of Research and Technological Innovation.

${ }^{6}$ Programa Amazonas de Apoio a Pesquisa em Políticas Públicas em áreas Estratégicas or Amazonas Program of Research Support in Public Policies within Strategic Areas.
} 
A peculiarity of Amazon technological development in the sector of "Phytos" is that the largest part of Amazon patents of A6IK Class applied at INPI, has the application done on behalf of independent inventors or natural person (91\%), they have not institutional character. The significant participation of independent inventors in the sector of phytotherapeutic agents in Brazil had already been reported in the work of Vasconcellos, Esquibel and Lage (2004), which evidenced that the application of more than a half of patents in this technological field was done on behalf of independent inventors.

Possible explanations for this fact are formulated herein, as: (I) Small business owners deposit patent applications as natural persons, and not as juridical persons, in order to decrease the procedural costs charged by INPI; (2) Investigators deposit the results of their researches developed within Brazilian STI, on their own behalf. This situation is repetitive, probably, thanks to unfamiliarity of Brazilian investigators with the Law of Industrial Property \# 9.279/1996, which in its Article 88th establishes that "The invention and the utility model pertain exclusively to the employer, when resulting from a work contract whose execution occurs in Brazil, having as purpose the investigation or inventive activity; or when it results from the nature of the services for which the employee was hired". The third possible explanation is that (3) They really result from natural persons, that is, from independent and not institutionalized inventors. In this last case, the problem falls over the sphere of MP 2186-16/200I, created to regulate the Convention on Biological Diversity (CBD) in the Brazilian territory. The MP 2186-16/200I determines that the access to the component of genetic asset in Brazil is authorized only to Brazilian institutions, public or private, exerting activities of research in biological and similar areas. So, there are no paths in the moment to authorize it to independent inventors.

Facing the impossibility of public investigator to register an institutionally developed patent on his/her own behalf, the Law of National Innovation ( $N^{\circ}$ 10973/04) to stimulate the innovation in the ambit of federal research institutions enables incentives to public investigators who are involved in activities of technological innovation (Chapter I, Article Ist), anticipating the possibility of a public server or employee to receive pecuniary retribution from the STI or support institution, with which his/her respective federal research institution has signed an agreement (Chapter III, Article 8th, $\S 2$ nd), besides to provide the receipt of the fellowship for stimulation to innovation (Chapter III,
Article 9th, $\S$ Ist). To the inventor, it is assured yet the minimum participation of $5 \%$, and the maximum one of I/3 from the economic gains received by the STI, resulting from an agreement for technology transference and license for granting of right of use or exploitation of the protected creation (Chapter III, Article 13th).

It is still uncertain the destination of $91 \%$ of the patent applications found by this investigation, in the A6IK Class of IPC and applied by Amazon inventors at INPI on behalf of independent inventors. It is important to detach that of the "phytos" patent applications, nine $(\mathrm{N}=9)$ requests where already filed, and only eleven $(\mathrm{N}=\mathrm{II})$ are still in course at INPI, with only two $(\mathrm{N}=2)$ of them pertaining to juridical person; therefore, there are nine $(\mathrm{N}=9)$ patent applications deposited by independent inventors from Amazonian States in the A6IK Class of IPC, which could be refused, representing so a loss of regional innovative efforts.

Besides, the patents associating resources of the Brazilian genetic asset with traditional knowledge (CTA), for instance, should have their investigation processes analyzed by the Board of Management of Genetic Resources (CGen), created to coordinate the implantation of policies for the management of Brazilian genetic asset and establish technical rules for such purpose (BRASIL, 2002). The Resolution 23 of 2006 of CGen establishes the mechanism of verification of accomplishment of MP $N^{\circ} 2186-16 / 2001$, for purposes of granting of invention patents by INPI. This regulation was implemented at INPI by means of Resolution 207, and it determines that the holder of patent applications resulting from access to Brazilian genetic asset (PG), or patent applications resulting from associated traditional knowledge (CTA), should inform the number and date of the access authorization issued by CGen, up to the moment of the patent application examination.

Some changes are being developed in the technical procedures of CGen, such as the issuing (on August 27th, 2009) by Ministry of Environment (MMA) of the Deliberation \# 246 that accredited the National Council of Scientific and Technological Development (CNPq) to authorize: (I) other institutions to develop the activities of access to samples of a component of the genetic asset, for purposes of scientific research; and (2) to send samples of a component of the genetic asset to an institution settled overseas, only for purposes of scientific research (published in the Union Official Daily Newspaper, September 16th, 2009). Thus, such cases are no more analyzed by CGen, but by CNPq. 
Currently, the entrepreneurs interested in exploit the market of Amazon biodiversity, and develop activities of bioprospection of plants obtained, mainly, in areas inhabited by traditional populations, need to follow up the meetings of CGen thematic chambers to understand the rules, avoiding so future problems for their companies. The companies that achieve to grow exploiting this market niche, regularly, hire attorneys that actively participate of CGen thematic chambers. The accomplishment of technical norms of the National Health Surveillance Agency (ANVISA) and the Ministry of Agriculture, Livestock and Supply (MAPA), for instance, are indispensable for the commercialization, mainly, of phytotherapeutic agents and products based on honey, respectively, in Brazilian territory.

According to Revilla (2007), the market of phytotherapeutic agents of Amazonian origin faces obstacles related to overcoming of Brazilian and worldwide phytosanitary barriers, such as: the lack of information about the dosage, side effects, time of use, among others; being so indispensable the technoscientific investments for previous studies, pharmaceutical formulations, and registrations, in order to separate the phytotherapeutic agents from the teas of conventional and empiric use. To be able to transcend the local market, reaching the domestic and international markets adding value to these products, all the regulations must be accomplished (Frickmann and Vasconcellos, 2010).

The Amazonia is not only Brazilian (Clement and Higuchi, 2006), but pertains to more than eight countries: Bolivia, Colombia, Ecuador, French Guyana, Peru, Cooperative Republic of Guyana, Suriname, and Venezuela. These genetic resources are exportation merchandises of the commodities type, without aggregated value (Lasmar, 2005). This situation, probably, is also more attractive for the holders of 150 international patents utilizing Amazon genetic resources, identified by Homma (2008).

Currently, there is a lack of large sized companies, as of phytotherapeutic sectors, as of phytocosmetic ones, settled in the Brazilian Amazonia (Frickmann and Vasconcellos, 20II). The excess of technical regulatory norms over these markets of international interest, effectively, embarrasses the growth of small and middlesized Amazon companies. Productive arrangements and efficient policies, if adopted, could create a productive environment favorable to these sectors, stimulating so the partnership with large sized companies settled in other Brazilian States and even with international companies, by means of networks and technological projects. Such actions could stimulate the growth of Amazon productive sector of phytotherapeutic and phytocosmetic agents, invigorating the biotechnological market; a sector that trends to add more value to bioproducts, breaking the vicious cycle of predatory exploitation of biodiversity.

\section{Conclusion}

Despite the existence of seventy two (72) research groups in the Amazon Region investigating themes such as phytotherapeutic and phytocosmetic agents, or medicinal plants, it was verified that these research efforts in the scientific area do not, effectively, result in innovative products and processes protected by the system of patents.

The low amount of patent applications of phytotherapeutic and phytocosmetic agents originated from the Amazon States, associated to the result verified in this present investigation, that none of these patents was granted so far, reveals that the potential of Amazon biodiversity is not being adequately utilized in Brazilian Amazonian to the generation of inventions in the areas of phytotherapeutic and phytocosmetic agents, which could significantly contribute for add value to Amazonian bioproducts and, consequently, for the sustainable development of Amazonian Region.

In order to improve the patent development of Amazonian States in the areas of phytotherapeutic and phytocosmetic agents, it is necessary the continuation of stimulation to in-company research, by means of edicts such as PAPPE from FAPEAM, and others from the Financier of Studies and Projects (FINEP), CNPq, and Coordination of Improvement of Higher Education Staff (CAPES). It is also necessary, the amplification of support strategies for the regional extractive activities, in which is referred to planning, coordination, and management of economic interests of extractors and merchants, in order to organize the demand of products offering as well.

The reality is that Brazil is still acquiring international experience in technological innovation and, obviously, the Amazonian Region is trying to follow up this process, facing great difficulties for that. So, more efforts are necessary for the conversion of phytotherapeutic and phytocosmetic researches into innovative and intellectually protected 
products, effectively competitive in the Brazilian and international markets.

Face to necessity to amplify the inventory of Brazilian Amazonian species and, at the same time, become the market of bioproducts viable on sustainable bases, it is important to increase the scientific sponsorships for the Brazilian Amazonia, anticipating also the existence of Brazilian sponsorships to large scale research projects, that is, with up to thirty years of duration. Besides, it is a priority the implementation of FAPs in all states of Brazilian Amazonia Region. The capacity in innovation should continue to be offered and expanded, addressed mainly to federal scientific institutions, companies, and extractive communities participating in technological chains that are strategic for the development of commercial sectors.

As already highlighted by Querido, Lage and Vasconcellos (20II) the support to universities NITs (Nuclei of Technological Innovation) is also indispensable for the regional innovation, as it will amplify the strategies of transference of technologies of patents produced in the ambit of federal universities, assuring benefits to innovative efforts from Brazilian investigators in the field of Amazonian biotechnology. Other impressive point is the creation of a Brazilian Law of Biodiversity able to cease the discussions about the MP 2186-16/2001, and including into its scope, as strategies for stimulation to innovation and conservation, as a program for stimulation to sustainable utilization of biodiversity and Amazon genetic resources, resulting from complaints from diverse Amazonian representatives: entrepreneurs, STI, traditional populations and governors.

It is urgent, so, a politic adequacy of actions promoted by different public organisms, mainly the federal ones, once the reality offers an entanglement of opportunities and obstacles crossing the legal sphere, creating an aspect of Brazilian ambiguity respecting to the actual interest on the Amazonian biotechnological development, in sectors considered politically strategic.

Only with the maturation and Brazilian comprehension about the complexities involving the biotechnological sectors making use of the Amazonian biodiversity as matrix, is that both, the country and the Amazonia, could understand the actual potential of the Amazon biodiversity to generate foreign currency, and so ascend to and definitely achieve an international detached position in the biotechnological development, and effectively consolidate the production and innovation in the field of Brazilian phytotherapeutic and phytocosmetic products.

\section{Acknowledgements}

This investigation obtained financial support from the Foundation of Support to Research of the State of Amazonas (FAPEAM), the Foundation of Support to Research of the State of Rio de Janeiro (FAPERJ). Technological, logistical, and intellectual support from the Postgraduate Program in Vegetal Biotechnology of the UFRJ (Federal University of Rio de Janeiro) and the INPI (National Institute of Industrial Property).

\section{Bibliographic References:}

AMAZONAS (2007a). PAPPE. Amazonas Ciêncial FAPEAM. Amazonas, Brasil. 3(6), 6-27.

AMAZONAS (2007b). Catálogo PIPT e Temático: resumos. Amazonas/FAPEAM, Amazonas, Brasil.

AMAZONAS (2009). Relatório de Gestão. Fundação de Amparo á Pesquisa do Estado do Amazonas (FAPEAM), Amazonas, Brasil.

AMAZONAS (2006). Lei de Inovação Tecnológica. N. ${ }^{\circ}$ 3.095, de 17 de Novembro. Amazonas, Brasil.

ARRUDA, A.C. (2008). Cosméticos um caminho para a valorização da Biodiversidade Amazônica. Revista T \& C Amazônia. 6(14), 23-34.

ARRUDA, A.C.(2009). Rede de inovação de dermocosméticos na Amazônia: o uso sustentável de sua biodiversidade com enfoques para as cadeias produtivas da castanha-do-pará e dos óleos de andiróba e copaíba. Parcerias Estraégicas. Brasilia/DF, Brasil 14(29), 145-172.

BECKER, B.K. (2009). Uma visão de futuro para o coração florestal da Amazônia. In: Pires, C. T. (Ed.), Um projeto para a Amazônia no século 2I: desafios e contribuições. Centro de Gestão e Estudos Estratégicos - CGEE. Brasília/DF, Brasil, pp: 38-86. 
BRASIL (2002). Medida Provisória ${ }^{\circ} 2.186-16$, de 23 de agosto de 200I, Decreto ${ }^{\circ} 3.945$, de 28 de setembro de 200I, Resolução $n^{\circ}$ 001, de 8 de julho de 2002. Ministério do Meio Ambiente - MMA/ CGen. Brasília - DF, Brasil.

BRASIL (2004). LEI N $N^{\circ} 0.973$ de 02 de dezembro de 2004. Dispõe sobre incentivos à inovação e à pesquisa científica e tecnológica no ambiente produtivo e dá outras providências. Brasília, Brasil.

BRASIL (20I0a). Amazônia Legal: área de atuação/situação geográfica. Superintendência do Desenvolvimento da Amazônia, Ministério da Integração Nacional. Brasília, Brasil.http://www.redegoverno.gov.br/defaultCab. asp?idservinfo $=35614 \&$ url=http://www.ada.gov.br/index . php?option $=$ com _content $\&$ task $=$ category \&sectionid $=9 \& i$

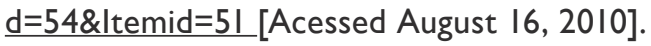

BRASIL (20I0b). Doutores 20I0: Estudo da demografia da base técno-científica brasileira. Centro de Gestão e Estudos Estratégicos (CGEE). Brasília - DF, Brasil.

BRASIL, (2010c). Relatório de Gestão 2009. Ministério do Desenvolvimento da Indústria e do Comércio Exterior (MDIC)/ Superintendência da Zona Franca de Manaus (SUFRAMA) Amazonas, Brasil.

CLEMENT, C.R. \& Higuchi, N. (2006). A Floresta Amazônica e o Futuro do Brasil. Cienc. Cult. 44-49. [online] http://cienciaecultura.bvs.br/pdf/cic/v58n3/ al8v58n3.pdf [Accessed November 18, 2010].

CRUZ, C.H.B.A (1999). A universidade, a empresa e a pesquisa que $\circ$ país precisa. Revista Humanidades, 45(I), 15-29.

FONSECA, M.G.D. , Poz, E.D. , Silveira, J.M.F.J. (2004). Biotecnologia vegetal e produtos afins: sementes, mudas e inoculantes. In: Silveira, M.F.J.; Dal Poz, E.M.; Assad, L.A. (Org.) Biotecnologia e Recursos Genéticos: Desafios e oportunidades para o Brasil. FINEP. Campinas, Brasil. Pp.166-197.

FREITAS, A (2007). Estrutura de mercado do segmento de fitoterápicos no contexto atual da indústria farmacêutica brasileira. Ministério da Saúde, Brasília-DF/Brasil.
FRICKMANN, F.S.S., Vasconcellos, A.G. (2010) Oportunidade para a inovação e aproveitamento sustentável da biodiversidade amazônica em bases sustentáveis. Revista T\&C Amazônia. 8(19), 20-28. https:// portal.fucapi.br/tec/artigos.php

FRICKMANN, F. dos S. e S., Vasconcellos, A. G. (20II). Investimentos em ciência, tecnologia e inovação na amazônia brasileira: o caminho da conversão dos investimentos públicos em biotecnologias regionais. XIV Congreso Latino-Iberoamericano de Gestión Tecnológica, 19,20 y 21 de octubre de 20II, Lima - Perú (CD-ROM).

HASENCleVer, L., Antunes, A., Klein, H., Mendes, F., Lopes, R. Hoefle, D., Castro, L.L., Donati, L., Cacicedo, T. (2009). Diagnóstico dos desafios e oportunidades no mercado de plantas medicinais e fitoterápicos brasileiro. Relatório Final do Centro de Gestão de Estudos Estratégicos - CGEE. Brasília-DF/Brasil.

HOMMA, A. K. O. Extrativismo,Biodiversidade e Biopirataria na Amazônia (2008). Texto para Discussão 27. Embrapa Informação Tecnológica, Brasília-DF, Brasil.

JORNAL DA CIÊNCIA (2009). Estados buscam amparo para pesquisa científica e tecnológica. Sociedade Brasileira Para o Progresso da Ciência. 23(64I). Rio de Janeiro.

MIGUEL, L.M. (2007). Uso Sustentável da Biodiversidade na Amazônia Brasileira: experiências atuais e perspectiva das bioindústrias de cosmético e fitoterápico. Universidade de São Paulo/Programa de Pós-Graduação em Geografia Humana, São Paulo/BR.

LASMAR, D.J. (2005). Valorização da Biodiversidade: capacitação e inovação, tecnologia na fitoindústria do Amazonas. Tese de doutorado. UFRJ-Coppe, Rio de Janeiro, Brasil.

OECD (2005). Oslo Manual: Guidelines forcollecting and interpreting Innovation data. 3rd Eddition Paris: OECD/ EUROSTAT. Paris.

QUERIDO, A.L.de S., Lage, C.L.S., Vasconcellos, A.G. (20II). What is the Destiny of Patents of Brazilian University? Journal of Technology Management \& Innovation, 6(I), 46-57. 
REVILLA, J. (2007). Mapeamento da Biodiversidade Amazônica: potencialidade dos fitos. Revista $T$ \& $C$ Amazônia. 5(II), I8- 25.

SIMÕES, C.M.O. \& Schenckel, E.P. (2002). A pesquisa e a produção brasileira de medicamentos a partir de plantas medicinais: a necessária interação da indústria com a academia. Revista Brasileira de Farmacognósia. I2(I), 35-40.

UNION OFFICIAL DAILY NEWSPAPER (2009). September 16th, Deliberação $N^{\circ}$. 246 de 27 de agosto de 2009. Ministério do Meio Ambiente. Brasília-DF, Brasil.

VASCONCELLOS, A.G. Rodrigues, R.L. (2008). Propriedade intelectual e gestão do conhecimento associada à biodiversidade. In: Loiola, M.I.B. Baseia, I.G. Lichston, E.D. (Orgs.), Anais do $59^{\circ}$ Congresso Nacional de Botânica. Ed. Imagem Gráfica, Natal(RN)/ Brasil. pp. 203-206.

VASCONCELLOS, A.G., Esquibel, M.A., Lage, C.L.S. (2004). Proteção patentária de fitoterápicos no Brasil: um estudo sobre os depósitos de patente ao longo da década de 90. Revista Brasileira de Plantas Medicinais, 7(I), 5I-56. 
J. Technol. Manag. Innov. 20II,Volume 6, Issue 4 